\title{
Sex and salt intake dependent renin-angiotensin plasticity in the liver of the rat
}

\author{
Paulina Pidikova, Pavel Svitok, Iveta Herichova \\ Department of Animal Physiology and Ethology, Faculty of Natural Sciences, \\ Comenius University Bratislava, Slovak Republic \\ E-mail: herichova1@uniba.sk
}

Objective. Epidemiological studies confirm that hypertensive patients respond differently to renin-angiotensin system (RAS) inhibition depending on their gender. The aim of present work is to focus on sex-dependent differences in RAS regulation under conditions of increased salt intake.

Method. To investigate RAS, we measured the expression of angiotensinogen (Agt) mRNA, angiotensin receptor type 1 (AT1) mRNA and mitochondria assembly receptor (MasR) in the liver of rats under control conditions and after feeding with a salt diet $(2 \% \mathrm{NaCl})$. In parallel, vascular endothelial growth factor A (VEGF-A) mRNA was analyzed.

Results. Regression analysis revealed sex-dependent differences in the correlation between mRNA expression of AT1 and that of Agt, MasR and VEGF-A in both groups. There was a significant negative correlation between AT1 and Agt mRNA expression in the male control group, but this correlation disappeared in males exposed to a salt diet. In females, AT1 and Agt expression correlated only in the group exposed to the salt diet. In control males, there was a borderline trend to correlation between AT1 and MasR mRNA expression. The correlation between AT1 and VEGF-A mRNA expression was significant only in the control females, however, after exposure to a salt diet, this correlation diminished.

Conclusions. We hypothesize that RAS components expression is compensated differently in males and females. The observed loss of compensatory relationships in RAS between AT1 and Agt and AT1 and MasR in male rats under a salt diet can contribute to the differences observed in human with hypertension associated with an unhealthy diet.

Key words: hypertension, salt diet, male, female, AT1 receptor, angiotensinogen, Mas receptor, VEGF-1

In 2015, cardiovascular diseases (CVDs) caused nearly one third of all deaths in Europe (Townsend et al. 2016). Hypertension is one of the most important risk factors for the development of other CVD (Shapo et al. 2003). Many epidemiological studies have revealed risk factors that are associated with an increased blood pressure. Some of these factors include age, obesity, dyslipidemia, and an unhealthy lifestyle (increased dietary salt intake, alcohol consumption, smoking, etc.). All of these studies also revealed significant sex-dependent differences in the prevalence of hypertension (Shapo et al. 2003; Bener et al. 2004; Wei et al. 2015). Some epidemiological studies have reported that incidence of hypertension is lower in premenopausal women than in age-matched men, however, after menopause, this difference disappears and the incidence of hypertension starts to rise in women (Nelson and Coady,

Corresponding author: Iveta Herichova, Department of Animal Physiology and Ethology, Faculty of Natural Sciences, Comenius University Bratislava, Ilkovicova 6, 84215 Bratislava, Slovak Republic; phone: 0042160296 572; e-mail: herichova1@uniba.sk. 
2008; Sandberg and Ji 2012; Mozaffarian et al. 2016). Blood pressure is higher in women after menopause than in premenopausal women (Staessen et al. 1989). In Europe, there were more death incidentes from cardiovascular diseases in men than in women before 65 years of age in 2015 (Townsend et al. 2016).

The renin-angiotensin system (RAS) plays a key role in the regulation of blood pressure and homeostasis of electrolytes in the body fluids. Many drugs used in the widespread treatment of hypertension are based on targeting of RAS components (Steckelings et al. 2011).

The liver is the primary source of angiotensinogen (Agt) for central RAS in the circulation, and other components of the RAS are also expressed in the liver (Lubel et al. 2009; Matsusaka et al. 2012). The main effector molecule of the classical axis of RAS is angiotensin II (AngII). AngII is synthesized from angiotensinogen by a two-step enzymatic cascade. Agt is converted by renin to angiotensin I (AngI), and AngI is cleaved by angiotensin converting enzyme (ACE) to AngII in the following step (Reid 1998). Through the AT1 receptor, AngII mediates vasoconstriction and fibrosis progression and induces the proliferation of hepatocytes in the liver. AngII also mediates some key aspects of liver tissue repair - myofibroblast proliferation, the infiltration of inflammatory cells and collagen synthesis (Yoshiji et al. 2001; Bataller et al. 2005).

Recent studies have revealed that AngII metabolite angiotensin (1-7) [Ang (1-7)] also plays a role in the regulation of blood pressure. Ang (1-7) is a part of the so-called second axis of RAS that shows antagonistic effects against the classical first axis (Iwai and Horiuchi 2009; Slamkova et al. 2016). Ang (1-7) acts via the Mas receptor (mitochondria assembly receptor) (Santos et al. 2003) to induce vasodilatation and inhibits tissue remodeling and fibrosis in the liver (Lubel et al. 2009).

The higher intake of $\mathrm{NaCl}$ can affect the blood pressure and negative consecutive effects can be reversed by the suppression of RAS activity (He and MacGregor 2003; Cholewa et al. 2005). However, the treatment of hypertension is complicated by regulatory feedback connections between RAS components. The inhibition of AngII formation leads to an increased expression of renin in the kidney (Kammerl et al. 2002). Increased levels of AngII resulted in a significant decrease in angiotensin receptor binding in the rat mesenteric artery (Gunther et al. 1980). After ACE activity blockade by ACE inhibitors, AngII can still be produced by other enzymes, mainly by chymase. These ACE-independent pathways may contribute to the restoration of AngII activity through the AT1 receptor or increase the stimulation of the second axis of RAS (Nehme and Zibara 2017).

Local tissue RAS in the liver is mainly associated with regeneration processes after injury, fibrosis progression or cell proliferation and apoptosis in healthy and malignant tissue (Koh et al. 2010; Moreira de Macedo et al. 2014; Simoes E Silva et al. 2017). On the other hand, very little is known about role of liver RAS in the regulation of hypertension. In recent studies an attention was mainly focused on the analyses of RAS components expression in the kidneys (Rands et al. 2012; Mao et al. 2013).

Therefore, our work is focused on the analysis of the reciprocal interactions of RAS in the liver in a higher salt diet model in males and females.

\section{Materials and methods}

The experimental protocol was approved by the Ethical Committee for the Care and Use of Laboratory Animals at the Comenius University in Bratislava and the State Veterinary and Food Administration of the Slovak Republic Committee of Slovak Republic. The investigation conditions were in accordance with the guidelines with the National Institute of Health Guide for the Care and Use of Laboratory Animals (NIH Publications No. 80-23) revised 1996 guidelines for the Care and Use of Laboratory Animals published by the U.S. National Institutes of Health.

Animals. Parental animals (Velaz, Prague, Czech Republic) were housed in a temperature-controlled room $\left(21 \pm 2^{\circ} \mathrm{C}\right)$ under a $12 \mathrm{~h}: 12 \mathrm{~h}$ light:dark regime with lights on at 7:00 h. After distinguishing the phase of the ovulation cycle, females were mated with males. Mating was confirmed by the detection of sperm in a vaginal smear. After that females were transferred to the separate cages. During the gravidity, the females were fed with standard laboratory chow. After birth, litters were culled to four females and four males per dam. All offspring were fed a diet with normal salt content $(0.5 \% \mathrm{NaCl})$ ad libitum. Systolic blood pressure (SBP) was measured regularly from the $10^{\text {th }}$ week until the end of the experiment. At the $14^{\text {th }}$ week of the age, the animals of both sexes were split into two groups. The first group was fed with standard laboratory chow $(0.5 \% \mathrm{NaCl})$ ad libitum and served as a control group, while the second group was fed a higher salt content chow (2\% $\mathrm{NaCl}$ ) ad libitum during the last three weeks of the experiment (weeks 15-17). Sampling was performed at the $17^{\text {th }}$ of the age. Livers were removed and stored at $-80^{\circ} \mathrm{C}$ until RNA isolation was performed. The 
heart and the left ventricle were weighed. Relative heart weight (RHW) and relative left ventricle weight (RVW) were calculated as a ratio to the body weight (BW).

RNA isolation and real-time PCR. Total RNA from the liver (70 $\mathrm{mg}$ of tissue) was isolated with the use of RNAzol (MRC, USA). The synthesis of cDNA was carried out with the use of kit ImProm-II Reverse Transcription System II (Promega, USA) according to the manufacturer's instructions. The quantification of cDNA was performed by real-time PCR using the QuantiTect SYBR Green PCR kit (Qiagen, Germany) and the StepOne ${ }^{\mathrm{ma}}$ Plus Real-Time PCR System thermocycler (Applied Biosystems, USA). The primers used for amplification were: Agt (AH003514.1) sense 5'-CTC AGG CCA AGC TGT CTA CC-3', antisense 5'-CGT AGA TGG CGA ACA GGA AC-3'; at $1 r$ (NM_030985) sense 5'-CCA AGA TGA CTG CCC CAA G-3', antisense 5'-ATC ACC ACC AAG CTG TTT CC-3'; MasR (NM_012757.2) sense 5'-CCA GAG AGA AAA TGG CCT GAA G-3', antisense 5'-TCC TCA TCC GGA AGC AAA GG-3'; and vegf- $a$ (NM_031836.3) sense 5'-GCA GCG ACA AGG CAG

Table 1

Body weight, relative heart weight, relative left ventricle weight and systolic blood pressure of rats at the end of experiment in males and females with $(2 \% \mathrm{NaCl})$ or without (Control) higher salt diet.

\begin{tabular}{|c|c|c|c|c|c|c|}
\hline Parameter & Group & Sex & Mean & & SEM & p-value \\
\hline \multirow[t]{4}{*}{ BW } & \multirow[t]{2}{*}{ Control } & Males & 471.7 & \pm & 12.68 & $\mathrm{a}$ \\
\hline & & Females & 267.3 & \pm & 6.89 & b \\
\hline & \multirow[t]{2}{*}{$2 \% \mathrm{NaCl}$} & Males & 450.2 & \pm & 9.50 & a \\
\hline & & Females & 267.8 & \pm & 7.39 & b \\
\hline \multirow[t]{4}{*}{ RHW } & \multirow[t]{2}{*}{ Control } & Males & 2.2 & \pm & 0.07 & $\mathrm{a}$ \\
\hline & & Females & 2.6 & \pm & 0.06 & b \\
\hline & \multirow[t]{2}{*}{$2 \% \mathrm{NaCl}$} & Males & 2.2 & \pm & 0.02 & a \\
\hline & & Females & 2.6 & \pm & 0.04 & b \\
\hline \multirow[t]{4}{*}{ RVW } & \multirow[t]{2}{*}{ Control } & Males & 1.2 & \pm & 0.06 & $\mathrm{a}$ \\
\hline & & Females & 1.5 & \pm & 0.08 & $\mathrm{~b}$ \\
\hline & \multirow[t]{2}{*}{$2 \% \mathrm{NaCl}$} & Males & 1.2 & \pm & 0.03 & a \\
\hline & & Females & 1.4 & \pm & 0.04 & $\mathrm{~b}$ \\
\hline \multirow[t]{4}{*}{ SBP } & \multirow[t]{2}{*}{ Control } & Males & 130.0 & \pm & 2.97 & $\mathrm{a}$ \\
\hline & & Females & 121.0 & \pm & 33.47 & $\mathrm{a}$ \\
\hline & \multirow[t]{2}{*}{$2 \% \mathrm{NaCl}$} & Males & 134.0 & \pm & 3.86 & $\mathrm{a}$ \\
\hline & & Females & 124.4 & \pm & 4.89 & $\mathrm{a}$ \\
\hline
\end{tabular}

Results from each physiological parameter were analyzed by two-way ANOVA (sex and salt diet) followed by post-hoc Tukey test. Values with the same letter are not significantly different. Data are given as a mean \pm SEM $(n=6-7)$. Abbreviations: BW - body weight; RHW - relative heart weight; RVW - relative ventricle weight; SBP - systolic blood pressure.
ACT AT-3', antisense 5'-GCA ACC TCT CCA AAC CGT TG-3'. Real-time PCR conditions were: hot-start at $95^{\circ} \mathrm{C}$ for $15 \mathrm{~min}$, followed by 40 cycles of $94^{\circ} \mathrm{C}$ for $15 \mathrm{~s}, 49-55^{\circ} \mathrm{C}$ for $30 \mathrm{~s}$ and $72^{\circ} \mathrm{C}$ for $30 \mathrm{~s}$. The specificity of the PCR reaction was validated by melting curve analysis.

Statistical analyses. Correlations in the expression of mRNA associated with RAS were evaluated by correlation analysis. Sex differences in BW, SBP, RHW, and RVW were analyzed by two-way ANOVA followed by post-hoc Tukey test or by regression analysis.

\section{Results}

According two-way ANOVA salt diet treatment did not influence the systolic blood pressure, body weight, RHW, and RVW in males or females, however, males showed higher body weight (ANOVA, $\mathrm{p}<0.001$ ) and lower RHW (ANOVA, $\mathrm{p}<0.001$ ) and RVW (ANOVA, $p<0.001$ ) compared to females in both, control as well as salt diet exposed animals (Table 1). SBP showed sex dependent difference with increased levels observed in males compared to females (ANOVA; $p<0.05$ ). However, post hoc analysis did not show differences between control and salt diet treated subgroups (Table 1). Systolic blood pressure was increasing in males, but not females (data not shown), during the experiment in the control group (Figure 1; $y=1.6164 x+99.234 ; R=0.425 ; \mathrm{p}<0.01$ ) and also in the group provided with the salt diet (Figure 1; $\mathrm{y}=1.5967 \mathrm{x}+105.33 ; \mathrm{R}=0.373 ; \mathrm{P}<0.01$ ).

Sex differences in the correlation between AT1 and Agt mRNA expression. Higher salt content in the food induced changes in the correlation between AT1 and Agt mRNA expression in a sex-specific manner. The higher salt diet was associated with a significant positive correlation between AT1 and Agt mRNA expression in female rats (Figure 2B; $\mathrm{y}=0.9483 \mathrm{x}+77.545 ; \mathrm{R}=0.915 ; \mathrm{p}<0.01)$. We did not observe this correlation in female rats kept under the control diet (Figure 2A). On the other hand, in control males, we observed a significant negative correlation between AT1 and Agt (Figure 2C; $y=-0.8905 x+1841.6$; $\mathrm{R}=0.858 ; \mathrm{p}<0.05)$. In males consuming the higher salt diet, this correlation diminished (Figure 2D).

Sex differences in the correlation between AT1 and VEGF-A mRNA expression. We observed a significant positive correlation between AT1 and VEGF-A mRNA expression in control female rats (Figure 3A; $y=0.3477 x+393.41 ; R=0.856 ; p<0.05$ ). In the female group exposed to the higher salt diet, this correlation diminished (Figure 3B). 


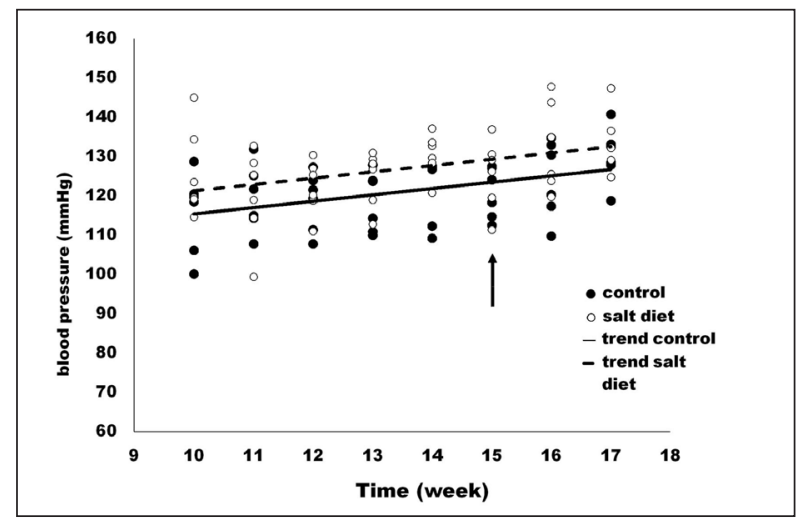

Figure 1. Systolic blood pressure in males in the control group $(\mathbf{O})$ and the group fed with the higher salt diet $(\bigcirc)$. The black arrow demonstrates when the feeding with the higher salt diet began. The $\mathrm{x}$-axis shows the age of animals. The solid line demonstrates a significant linear trend in control males, while the broken line demonstrates a significant linear trend in males fed with the higher salt diet.

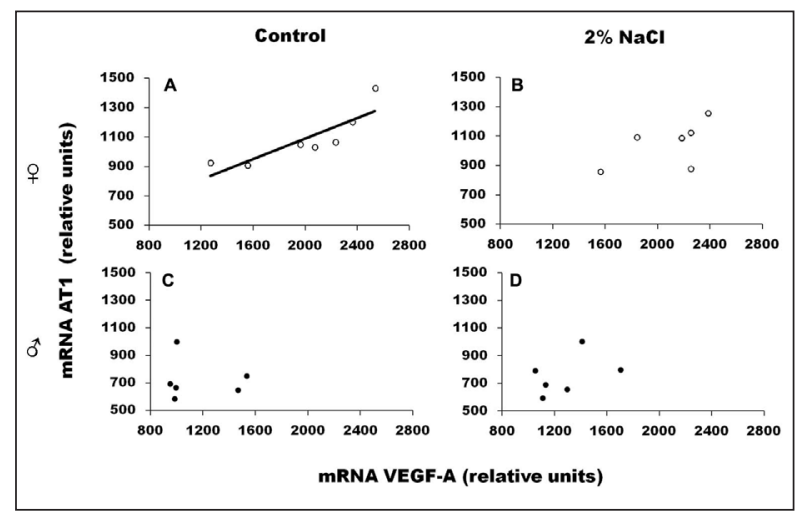

Figure 3. The correlation between AT1 and VEGF-A mRNA expression in the liver of female $(\bigcirc)(\mathbf{A}, \mathbf{B})$ and male $(\mathbf{O})(\mathbf{C}$, D) rats after feeding with the control $(\mathbf{A}, \mathbf{C})$ or higher salt diets $(\mathbf{B}, \mathbf{D})$. The solid line demonstrates a significant correlation $(\mathrm{p}<0.05 ; \mathrm{n}=6-7)$. Abbreviations: AT1 - angiotensin receptor type 1; VEGF-A - vascular endothelial growth factor A.

Sex differences in the correlation between AT1 and MasR mRNA expression. Correlation analysis revealed a borderline trend towards a correlation between AT1 and MasR mRNA expression in control male rats (Figure 4C; $y=0.3435 x+417.31 ; R=0.805$; $\mathrm{p}=0.051$ ), but not in female rats (Figure $4 \mathrm{~A}, \mathrm{~B}$ ). In male rats consuming higher salt diet, this trend diminished (Figure $4 \mathrm{D} ; \mathrm{y}=0.4739 \mathrm{x}+373.77 ; \mathrm{R}=0.712$; $\mathrm{p}=0.112$ ).

\section{Discussion}

Compensatory relationships inside the reninangiotensin system at the level of Agt, AT1, and MasR mRNA expression were studied and related

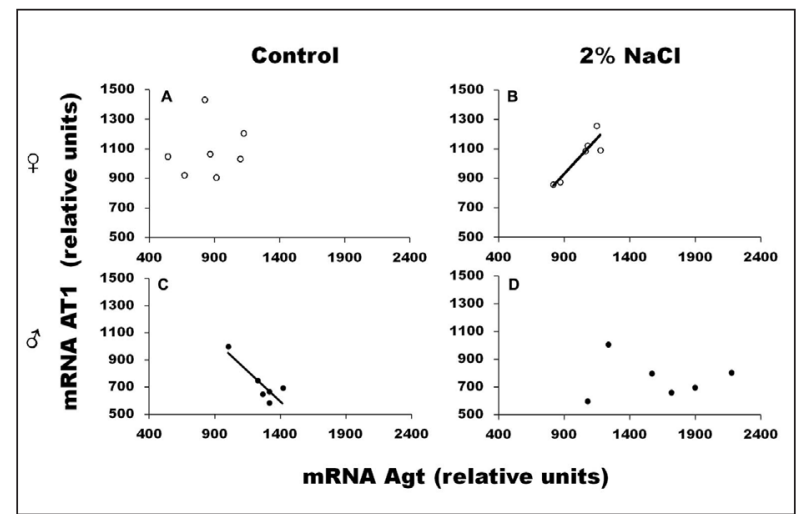

Figure 2. The correlation between AT1 and Agt mRNA expression in the liver of female $(O)(\mathbf{A}, \mathbf{B})$ and male $(\mathbf{O})(\mathbf{C}, \mathbf{D})$ rats after feeding with the control $(\mathbf{A}, \mathbf{C})$ or higher salt diets $(\mathbf{B}, \mathbf{D})$. The solid line demonstrates a significant correlation $(\mathrm{p}<0.05$; $\mathrm{n}=6-7$ ). Abbreviations: AT1 - angiotensin receptor type 1; Agt - angiotensinogen.

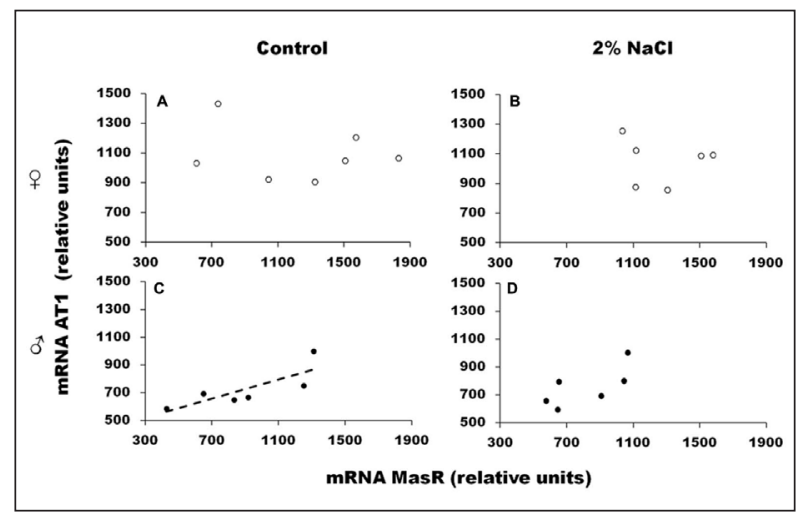

Figure 4. The correlation between AT1 and MasR mRNA expression in the liver of female $(\bigcirc)(\mathbf{A}, \mathbf{B})$ and male $(\mathbf{O})(\mathbf{C}, \mathbf{D})$ rats after feeding with the control $(\mathbf{A}, \mathbf{C})$ or higher salt diets $(\mathbf{B}$, D). The broken line demonstrates a borderline non-significant trend ( $\mathrm{p}=0.051 ; \mathrm{n}=6-7)$. Abbreviations: AT1 - angiotensin receptor type 1; MasR - mitochondria assembling receptor.

to VEGF-A mRNA levels in the liver of female and male rats. Correlation analyses revealed sex-dependent differences in response to the higher salt diet (Figure 5).

In males, we observed a negative correlation between AT1 and Agt mRNA expression in the control group. It is known that high Agt expression results in an increase in AngII levels (Kobori et al. 2001; Singh et al. 2003). Therefore, we hypothesize that increased Agt expression can (at least to some extent) also indicate an increase in AngII concentration. Several experimental evidences showed that AngII administration influenced AT1 expression. The treatment of the cells with AngII (in a model of BAC - Bovine adrenal fasciculata cells and PC12W 
cells - rat pheochromocytoma PC12 cell line) resulted in a decrease of AT1 receptor mRNA expression (Ouali et al. 1997). Rat cardiomyocytes exposed to AngII showed reduced AT1 receptor mRNA levels. The maximal decrease was observed after 6 hours of exposure. Then, the expression of the AT1 receptor started to restore to original levels (Chen et al. 2002). Increased levels of AngII resulted in a significant reduction of its binding on angiotensin receptors in the rat mesenteric artery (Gunther et al. 1980). Our previous study has revealed that chronic AngII infusion is associated with a trend towards the downregulation of AT1 expression in rat hearts compared to the control group (Herichova et al. 2013). All of the above-mentioned findings are in accordance with the recently presented negative correlation between Agt and AT1 mRNA expression. However, in some studies, this negative feedback was not observed. Treatment of the mouse neuronal cell line with AngII led to the increase in AT1 receptor expression (Mitra et al. 2010). In Sprague-Dawley male rats, chronic AngII infusion (13 days) did not change the expression of the AT1 receptor in the liver and kidney but increased the expression of AT1 mRNA in the adrenal gland (Harrison-Bernard et al. 1999).

Uncertainty about the effect of AngII on AT1 expression was explained by Schiffrin et al. (1983), who have described the bimodal interactions between AngII and the AT1 receptor. Treatment with lower doses of AngII leads to the suppression of AT1 receptor number, while high doses of AngII stimulate AT1 expression in vivo via an aldosterone-dependent mechanism. We suppose that the increase in AngII levels was rather low in our study and propose that this could generate a negative feedback for AT1 mRNA expression in the male control group.

In the male control group, we also observed a borderline significant correlation between AT1 and Mas receptor mRNA expression in the liver.

The Mas receptor and AT1 receptor belong to the family of G-coupled receptors (Reid 1998; Santos et al. 2003). The Mas and AT1 receptors can form both homodimers and heterodimers, with dimerization leading to crosstalk and the modulation of receptor activity (Lyngso et al. 2009). The co-expression of AT1 and Mas receptor in $\mathrm{CHO}-\mathrm{K} 1$ cells led to a decrease in AT1 receptor binding. On the other hand, Mas and AT1 co-expression was associated with an enhanced cell-surface expression of AT1 receptor (Kostenis et al. 2005). This experiment implies that the positive correlation between Mas and the AT1 receptor mRNA expression observed in our study works as a negative regulation pathway for AT1 receptor activity.

Both of the above-described correlations observed in the male control group were not observed in higher salt-treated males. It seems that the higher salt diet causes a disturbance in regulatory relationships inside the RAS. Similarly, we did not observe these compensation mechanisms in the female control group.

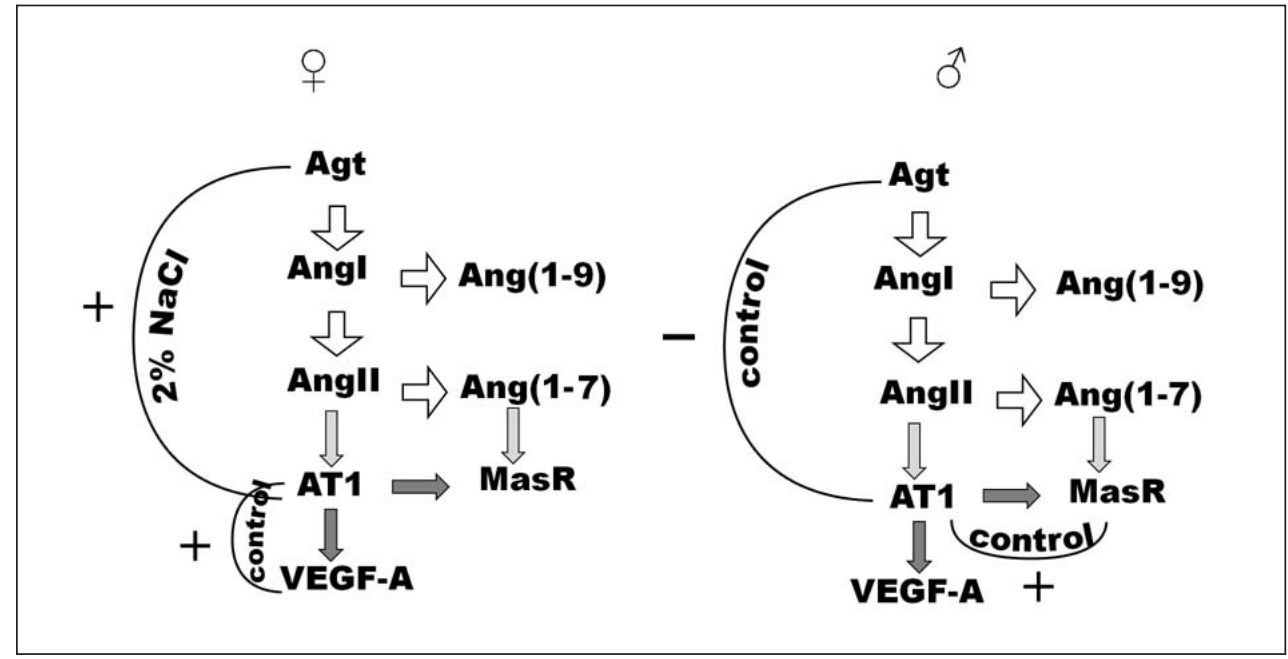

Figure 5. Gender differences in the expression of RAS components in the liver of rats consuming normal or higher salt $(2 \% \mathrm{NaCl})$ diets. The arch denotes a positive (+) or negative (-) correlation between RAS components under the conditions of control (control) or higher salt $(2 \% \mathrm{NaCl})$ diets. The white arrows indicate the progression of the AngII biosynthetic pathway, light grey arrows show the interaction with receptors and the dark grey arrows denote regulatory pathways. Abbreviations: Agt - angiotensinogen; AngI - angiotensin I; AngII - angiotensin II; Ang (1-7) - angiotensin (1-7); Ang (1-9) - angiotensin (1-9); AT1 - angiotensin receptor type 1; MasR - mitochondria assembly receptor; VEGF-A - vascular endothelial growth factor A. 
RAS components are also involved in angiogenesis, mainly by regulation of the expression of growth factors like VEGF-A (Imai et al. 2007). AngII, acting via the AT1 receptor, increased the expression of VEGF-A mRNA in human liver cancer cells (Fan et al. 2016). In animals treated with AngII infusion, the expression of VEGF-A (both protein and mRNA) in the retina increased. This effect was reversed after the administration of AT1 or AT2 antagonist (Zhang et al. 2004).

Angiogenesis mediated by VEGF-A is one of the key factors associated with the progression of cancer (Yoshiji et al. 2002; Ye et al. 2015; Zhao and Adjei 2015; Taurone et al. 2016). Numerous studies have revealed that the treatment of hypertension, targeted to RAS components (AT1 blockers, ACE inhibitors), is associated with the suppression of VEGF-A-mediated tumor development, better survival and a lower risk of the development of cancer (Yoshiji et al. 2002; Dai et al. 2015; Fan et al. 2016). Moreover, a recent study implied that breast cancer cells increased the expression of VEGF-A after exposure to high $\mathrm{NaCl}$ levels compared to control cells (Amara et al. 2016). In our experiment, we observed a significant positive correlation between the AT1 receptor and VEGF-A mRNA expression in the liver of the female control group. In the females with a higher salt intake, this correlation diminished.

We also analyzed the association of higher salt intake with changes in blood pressure and weight. Blood pressure in males gradually increased during the experiment, but this increase was independent of salt intake. In our study, the higher salt diet did not influence body weight, heart weight, left ventricle weight or systolic blood pressure in either sex.

Previously, it has been demonstrated that feeding with an $8 \%$ high salt diet led to a decrease in body weight and an increase in heart weight compared to the control group. Animals fed with a high salt diet also showed a significantly higher systolic and diastolic blood pressure compared to the control group (Ogihara et al. 2001; Hayakawa et al. 2015). The HW/BW ratio was significantly higher in the high salt group compared to the control group (Hayakawa et al. 2015; Igreja et al. 2019). We hypothesize that the above-mentioned studies referred to a more pronounced effect of the salt diet because they used a higher dose of salt (8\%) than our study (2\%), where changes induced by the salt diet were most probably compensated for by the homeostatic apparatus of the body. Another important factor may be the duration of the experiment. High salt intake led to much more pronounced changes in blood pressure after eight weeks of treatment compared to the second week of the experiment (Ogihara et al. 2001).

We revealed several interactions between RAS components and VEGF-A expression in the liver. These interactions were sex-dependent. Our findings are in accordance with previous research focused on gender-differences in RAS activity. Men and women respond differently to RAS pharmacological modulation. After treatment with lisinopril (ACE inhibitor), there was a greater decrease of blood pressure in men than in women (Falconnet et al. 2004). Women with congestive heart failure treated with angiotensin receptor blockers had better survival than women treated with ACE inhibitors (Hudson et al. 2007). Os et al. (1994) have revealed that a cough was reported three times more frequently in women than in men as a side effect of ACE inhibitors. It was shown that AT1 receptor binding is significantly higher in the kidney glomeruli of male rats compared to females (Rogers et al. 2007). A study of a cohort of patients from the Swedish Primary Care Cardiovascular Database (SPCCD) has revealed that there are also sex differences in antihypertensive drug prescription. Women were more frequently treated with diuretics and beta blockers than males, while ACE inhibitors and calcium channel blockers were more often prescribed to men. This discrepancy was explained by the different frequency of some side effects of treatments in men and women (Ljungman et al. 2014).

Sex-dependent differences in RAS treatment response can be associated with levels of sexhormones in men and women. After treatment with 2-methoxyestradiol (2ME2), a significant downregulation of AngII binding to the AT1 receptor was observed in rat liver epithelial cells. Expression of the AT1 receptor in cells was also suppressed after treatment with 2ME2 (Koganti et al. 2012).

All of these studies point to the important role of sex-dependent factors in the development and treatment of hypertension and related diseases that can be at least partly caused by differences in the internal RAS regulatory feed-back relationships.

To conclude, the main aim of this study was to analyze the regulatory feedback interactions inside RAS and their associations with VEGF-A mRNA expression in the liver. The observed interactions were sex-dependent and were modified after exposure to a higher salt diet. Compensatory correlations between AT1 and Agt, and AT1 and Mas receptors observed in males disappeared after exposure to a higher salt diet. The positive correlation between AT1 and VEGF-A observed in females also disappeared 
after the administration of a diet with $2 \% \mathrm{NaCl}$. We believe that our study may contribute to a better understanding of sex differences in the development of hypertension induced by a higher salt intake.

\section{Acknowledgement}

Research was supported by APVV-16-0209 and VEGA 1/0679/19.

\section{References}

Amara S, Alotaibi D, Tiriveedhi V. NFAT5/STAT3 interaction mediates synergism of high salt with IL-17 towards induction of VEGF-A expression in breast cancer cells. Oncol Lett 12, 933-943, 2016.

Bataller R, Gabele E, Parsons CJ, Morris T, Yang L, Schoonhoven R, Brenner DA, Rippe RA. Systemic infusion of angiotensin II exacerbates liver fibrosis in bile duct-ligated rats. Hepatology 41, 1046-1055, 2005.

Bener A, Al-Suwaidi J, Al-Jaber K, Al-Marri S, Elbagi I E. Epidemiology of hypertension and its associated risk factors in the Qatari population. J Hum Hypertens 18, 529-530, 2004.

Chen X, Cui Z, Zhang F, Chang W, Chen L, Liu L. Angiotensin II and cAMP regulate AT(1)-mRNA expression in rat cardiomyocytes by transcriptional mechanism. Eur J Pharmacol 448, 1-9, 2002.

Cholewa BC, Meister CJ, Mattson DL. Importance of the renin-angiotensin system in the regulation of arterial blood pressure in conscious mice and rats. Acta Physiol Scand 183, 309-320, 2005.

Dai YN, Wang JH, Zhu JZ, Lin JQ, Yu CH, Li YM. Angiotensin-converting enzyme inhibitors/angiotensin receptor blockers therapy and colorectal cancer: a systematic review and meta-analysis. Cancer Causes Control 26, 1245-1255, 2015.

Falconnet C, Bochud M, Bovet P, Maillard M, Burnier M. Gender difference in the response to an angiotensinconverting enzyme inhibitor and a diuretic in hypertensive patients of African descent. J Hypertens 22, 1213-1220, 2004.

Fan F, Tian C, Tao L, Wu H, Liu Z, Shen C, Jiang G, Lu Y. Candesartan attenuates angiogenesis in hepatocellular carcinoma via downregulating AT1R/VEGF pathway. Biomed Pharmacother 83, 704-711, 2016.

Gunther S, Gimbrone MA Jr, Alexander RW. Regulation by angiotensin II of its receptors in resistance blood vessels. Nature 287, 230-232, 1980.

Harrison-Bernard LM, El-Dahr SS, O'Leary DF, Navar LG. Regulation of angiotensin II type 1 receptor mRNA and protein in angiotensin II-induced hypertension. Hypertension 33, 340-346, 1999.

Hayakawa Y, Aoyama T, Yokoyama C, Okamoto C, Komaki H, Minatoguchi S, Iwasa M, Yamada Y, Kawamura I, Kawasaki M, Nishigaki K, Mikami A, Suzuki F, Minatoguchi S. High salt intake damages the heart through activation of cardiac (pro) renin receptors even at an early stage of hypertension. PLoS One 10, e0120453, 2015.

He FJ, MacGregor GA. Salt, blood pressure and the renin-angiotensin system. J Renin Angiotensin Aldosterone Syst 4, 11-16, 2003.

Herichova I, Soltesova D, Szantoova K, Mravec B, Neupauerova D, Vesela A, Zeman M. Effect of angiotensin II on rhythmic per2 expression in the suprachiasmatic nucleus and heart and daily rhythm of activity in Wistar rats. Regul Pept 186, 49-56, 2013.

Hudson M, Rahme E, Behlouli H, Sheppard R, Pilote L. Sex differences in the effectiveness of angiotensin receptor blockers and angiotensin converting enzyme inhibitors in patients with congestive heart failure--a population study. Eur J Heart Fail 9, 602-609, 2007.

Igreja B, Pires NM, Wright LC, Soares-da-Silva P. Effects of zamicastat treatment in a genetic model of salt-sensitive hypertension and heart failure. Eur J Pharmacol 842, 125-132, 2019.

Imai N, Hashimoto T, Kihara M, Yoshida S, Kawana I, Yazawa T, Kitamura H, Umemura S. Roles for host and tumor angiotensin II type 1 receptor in tumor growth and tumor-associated angiogenesis. Lab Invest 87, 189-198, 2007.

Iwai M, Horiuchi M. Devil and angel in the renin-angiotensin system: ACE-angiotensin II-AT1 receptor axis vs. ACE2-angiotensin-(1-7)-Mas receptor axis. Hypertens Res 32, 533-536, 2009.

Kammerl MC, Richthammer W, Kurtz A, Kramer BK. Angiotensin II feedback is a regulator of renocortical renin, COX-2, and nNOS expression. Am J Physiol Regul Integr Comp Physiol 282, 1613-1617, 2002.

Kobori H, Harrison-Bernard LM, Navar LG. Expression of angiotensinogen mRNA and protein in angiotensin IIdependent hypertension. J Am Soc Nephrol 12, 431-439, 2001.

Koganti S, Snyder R, Thekkumkara T. Pharmacologic effects of 2-methoxyestradiol on angiotensin type 1 receptor down-regulation in rat liver epithelial and aortic smooth muscle cells. Gend Med 9, 76-93, 2012. 
Koh SL, Ager EI, Christophi C. Liver regeneration and tumour stimulation: implications of the renin-angiotensin system. Liver Int 30, 1414-1426, 2010.

Kostenis E, Milligan G, Christopoulos A, Sanchez-Ferrer CF, Heringer-Walther S, Sexton PM, Gembardt F, Kellett E, Martini L, Vanderheyden P, Schultheiss HP, Walther T. G-protein-coupled receptor Mas is a physiological antagonist of the angiotensin II type 1 receptor. Circulation 111, 1806-1813, 2005.

Ljungman C, Kahan T, Schioler L, Hjerpe P, Hasselstrom J, Wettermark B, Bostrom KB, Manhem K. Gender differences in antihypertensive drug treatment: results from the Swedish Primary Care Cardiovascular Database (SPCCD). J Am Soc Hypertens 8, 882-890, 2014.

Lubel JS, Herath CB, Tchongue J, Grace J, Jia Z, Spencer K, Casley D, Crowley P, Sievert W, Burrell LM, Angus PW. Angiotensin-(1-7), an alternative metabolite of the renin-angiotensin system, is up-regulated in human liver disease and has antifibrotic activity in the bile-duct-ligated rat. Clin Sci (Lond) 117, 375-386, 2009.

Lyngso C, Erikstrup N, Hansen JL. Functional interactions between 7TM receptors in the renin-angiotensin system-dimerization or crosstalk? Mol Cell Endocrinol 302, 203-212, 2009.

Mao C, Liu R, Bo L, Chen N, Li S, Xia S, Chen J, Li D, Zhang L, Xu Z. High-salt diets during pregnancy affected fetal and offspring renal renin-angiotensin system. J Endocrinol 218, 61-73, 2013.

Matsusaka T, Niimura F, Shimizu A, Pastan I, Saito A, Kobori H, Nishiyama A, Ichikawa I. Liver angiotensinogen is the primary source of renal angiotensin II. J Am Soc Nephrol 23, 1181-1189, 2012.

Mitra AK, Gao L, Zucker IH. Angiotensin II-induced upregulation of AT(1) receptor expression: sequential activation of NF-kappaB and Elk-1 in neurons. Am J Physiol Cell Physiol 299, 561-569, 2010.

Moreira de Macedo S, Guimaraes TA, Feltenberger JD, Sousa Santos SH. The role of renin-angiotensin system modulation on treatment and prevention of liver diseases. Peptides 62, 189-96, 2014.

Mozaffarian D, Benjamin EJ, Go AS, Arnett DK, Blaha MJ, Cushman M, Das SR, de Ferranti S, Despres JP, Fullerton HJ, Howard VJ, Huffman MD, Isasi CR, Jimenez MC, Judd SE, Kissela BM, Lichtman JH, Lisabeth LD, Liu S, Mackey RH, Magid DJ, McGuire DK, Mohler ER 3rd, Moy CS, Muntner P, Mussolino ME, Nasir K, Neumar RW, Nichol G, Palaniappan L, Pandey DK, Reeves MJ, Rodriguez CJ, Rosamond W, Sorlie PD, Stein J, Towfighi A, Turan TN, Virani SS, Woo D, Yeh RW, Turner MB; American Heart Association Statistics Committee; Stroke Statistics Subcommittee. Heart Disease and Stroke Statistics-2016 Update: A Report From the American Heart Association. Circulation 133, e38-360, 2016.

Nehme A, Zibara K. Efficiency and specificity of RAAS inhibitors in cardiovascular diseases: how to achieve better end-organ protection? Hypertens Res 40, 903-909, 2017.

Nelson C, Coady S (eds). The Jackson Heart Study Data Book A Report to the Cohort and Community. NHLBI Health Information Center, Bethesda, 2008.

Ogihara T, Asano T, Ando K, Chiba Y, Sekine N, Sakoda H, Anai M, Onishi Y, Fujishiro M, Ono H, Shojima N, Inukai K, Fukushima Y, Kikuchi M, Fujita T. Insulin resistance with enhanced insulin signaling in high-salt diet-fed rats. Diabetes 50, 573-583, 2001.

Os I, Bratland B, Dahlof B, Gisholt K, Syvertsen JO, Tretli S. Female preponderance for lisinopril-induced cough in hypertension. Am J Hypertens 7, 1012-1015, 1994.

Ouali R, Berthelon MC, Begeot M, Saez JM. Angiotensin II receptor subtypes AT1 and AT2 are down-regulated by angiotensin II through AT1 receptor by different mechanisms. Endocrinology 138, 725-733, 1997.

Rands VF, Seth DM, Kobori H, Prieto MC. Sexual dimorphism in urinary angiotensinogen excretion during chronic angiotensin II-salt hypertension. Gend Med 9, 207-218, 2012.

Reid IA. The renin angiotensin system: physiology, pathophysiology and pharmacology. Adv Physiol Educ 20, 237245,1998

Rogers JL, Mitchell AR, Maric C, Sandberg K, Myers A, Mulroney SE. Effect of sex hormones on renal estrogen and angiotensin type 1 receptors in female and male rats. Am J Physiol Regul Integr Comp Physiol 292, 794-799, 2007.

Sandberg K, Ji H. Sex differences in primary hypertension. Biol Sex Differ 3,7, 2012.

Santos RA, Simoes E Silva AC, Maric C, Silva DM, Machado RP, de Buhr I, Heringer-Walther S, Pinheiro SV, Lopes MT, Bader M, Mendes EP, Lemos VS, Campagnole-Santos MJ, Schultheiss HP, Speth R, Walther T. Angiotensin-(1-7) is an endogenous ligand for the G protein-coupled receptor Mas. Proc Natl Acad Sci U S A 100, 8258-8263, 2003.

Schiffrin EL, Thome FS, Genest J. Vascular angiotensin II receptors in renal and DOCA-salt hypertensive rats. Hypertension 5, 16-21, 1983.

Shapo L, Pomerleau J, McKee M. Epidemiology of hypertension and associated cardiovascular risk factors in a country in transition: a population based survey in Tirana City, Albania. J Epidemiol Community Health 57, 734-749, 2003. 
Simoes E Silva AC, Miranda AS, Rocha NP, Teixeira AL. Renin angiotensin system in liver diseases: Friend or foe? World J Gastroenterol 23, 3396-3406, 2017.

Singh R, Singh AK, Alavi N, Leehey DJ. Mechanism of increased angiotensin II levels in glomerular mesangial cells cultured in high glucose. J Am Soc Nephrol 14, 873-880, 2003.

Slamkova M, Zorad S, Krskova K. Alternative renin-angiotensin system pathways in adipose tissue and their role in the pathogenesis of obesity. Endocr Regul 50, 229-240, 2016.

Staessen J, Bulpitt CJ, Fagard R, Lijnen P, Amery A. The influence of menopause on blood pressure. J Hum Hypertens 3, 427-433, 1989.

Steckelings UM, Paulis L, Unger T, Bader M. Emerging drugs which target the renin-angiotensin-aldosterone system. Expert Opin Emerg Drugs 16, 619-630, 2011.

Taurone S, Galli F, Signore A, Agostinelli E, Dierckx RA, Minni A, Pucci M, Artico M. VEGF in nuclear medicine: Clinical application in cancer and future perspectives (Review). Int J Oncol 49, 437-447, 2016.

Townsend N, Wilson L, Bhatnagar P, Wickramasinghe K, Rayner M, Nichols M. Cardiovascular disease in Europe: epidemiological update 2016. Eur Heart J 37, 3232-3245, 2016.

Wei Q, Sun J, Huang J, Zhou HY, Ding YM, Tao YC, He SM, Liu YL, Niu JQ. Prevalence of hypertension and associated risk factors in Dehui City of Jilin Province in China. J Hum Hypertens 29, 64-68, 2015.

Ye G, Qin Y, Lu X, Xu X, Xu S, Wu C, Wang X, Wang S, Pan D. The association of renin-angiotensin system genes with the progression of hepatocellular carcinoma. Biochem Biophys Res Commun 459,18-23, 2015.

Yoshiji H, Kuriyama S, Yoshii J, Ikenaka Y, Noguchi R, Nakatani T, Tsujinoue H, Fukui H. Angiotensin-II type 1 receptor interaction is a major regulator for liver fibrosis development in rats. Hepatology 34, 745-750, 2001.

Yoshiji H, Yoshii J, Ikenaka Y, Noguchi R, Yanase K, Tsujinoue H, Imazu H, Fukui H. Suppression of the renin-angiotensin system attenuates vascular endothelial growth factor-mediated tumor development and angiogenesis in murine hepatocellular carcinoma cells. Int J Oncol 20, 1227-1231, 2002.

Zhang X, Lassila M, Cooper ME, Cao Z. Retinal expression of vascular endothelial growth factor is mediated by angiotensin type 1 and type 2 receptors. Hypertension 43, 276-281, 2004.

Zhao Y, Adjei AA. Targeting Angiogenesis in Cancer Therapy: Moving Beyond Vascular Endothelial Growth Factor. Oncologist 20, 660-673, 2015. 